\title{
Green Mussels (Perna viridis L.) Culture in Mangrove Area Potentially Impacted by Heavy Metal
}

\author{
Suyono $^{{ }^{*}}$, Rossita Shapawi ${ }^{2}$ and Narto ${ }^{1}$ \\ ${ }^{1}$ Faculty of Fisheries and Marine Sciences, Pancasakti University \\ Jl. Halmahera No.KM. 01, Tegal,52121 Indonesia \\ ${ }^{2}$ Borneo Marine Research Institute, Universiti Malaysia Sabah \\ Universiti UMS, Sabah Port Bypass, 88400 Kota Kinabalu, Sabah, Malaysia \\ E-mail: suyono.faperi.ups@gmail.com
}

\begin{abstract}
The purposes of this study are to investigate the types of different collectors and their most effective height of installation in the green mussels cultivation (Perna viridis L.) impacted by heavy metal pollution in mangrove and non-mangrove waters; and to determine the content of heavy metals, especially $\mathrm{Pb}, \mathrm{Cu}, \mathrm{Cd}$, and $\mathrm{Hg}$ in green mussels cultivation. This research was conducted from April to September 2018 in the coastal area of Karangdempel, Losari Sub District, Brebes Regency. The method used in this research was experimental. The results showed that the growth of green mussels after 6 months period of maintenance reached $7-9 \mathrm{~cm}$ long, weighing 10-13 grams per head and yielded 23-30 heads per collector. The most effective mussel collector was net sacks installed at a height of $30 \mathrm{~cm}$ from the bottom of the water. The number of mussels per collector was more in mangrove location compared to those in the non-mangrove location, while their growth in length and weight were relatively the same. Heavy metal content in seawater and in the mussel meat are still within the permissible limits of the Indonesian National Standard, except for the Cu content in the mussel exceeding the allowable limit; but it was relatively still safe accoring to the Decree of the Director General of Drug Control and Food, Indonesian Ministry of Health, No. 03725/B/SK/1989. Pb content in sediments in both location of green mussels cultivation and the Cisanggarung River basin is still within the safe limits. The content of $\mathrm{Cd}, \mathrm{Cu}$, and $\mathrm{Hg}$ in sediments tends to be high. Heavy metal content both in mangrove and non-mangrove areas was not different as a result of mangrove reforestation dominated by seedlings and saplings with little influence on the quality of the water ecologically and economically.
\end{abstract}

Keywords: green mussels, heavy metals, mangroves

\section{Introduction}

Coastal waters are integral parts of the sea and coastal land with a complex relationship. The condition of the coastal waters is influenced by the activity in the watershed which empties into the coastal waters as well as the activities in the sea which are still relatively close to the coastal waters. The coastal waters of Karangdempel in the Losari Subdistrict, Brebes Regency as an estuary area of the Cisanggarung River Basin are likely to be affected by industrial wastes from Kuningan Regency, Cirebon City, and Cirebon Regency. In 2016, there were 5836 companies in Kuningan. Among them there were 3250 clothing companies and 2476 food companies (Kuningan Regency Central Bureau of Statistics, 2017). In Cirebon Regency, there were 841 companies in the chemical sector and 823 mining companies in 2016 (Cirebon Regency Central Bureau of Statistics, 2017) and in the same year in Cirebon City, there were 45 companies potentially producing waste (Cirebon City
Central Statistics Agency, 2017). The industrial waste often contains heavy metals which can endanger the lives of biota in river estuary waters. Several studies conducted by Heriyanto (2011), Kusumastuti et al. (2011) and Supriyantini and Soenardjo (2015), showed that the presence of mangroves can minimize or reduce the content of heavy metal contamination in the waters.

On the other hand, Karangdempel coastal waters is protected from large waves due to the presence of sand dunes so it is very strategic to be used as a development area for green mussels (Perna viridis L.) cultivation (Fisheries and Marine Service Office of Brebes Regency, 2008). Cultivation of green mussels is feasible to be developed because it is relatively easy, reasonable in costs and does not need to provide seeds specifically. This can be used as an additional business alternative for fishermen around Karangdempel, especially during the famine (Brebes Regency Indonesian Fishermen Association, 2017). 
The research purposes were investigate the types of different collectors and their most effective height of installation in the green mussels cultivation ( $P$. viridis L.) impacted by heavy metal pollution in mangrove and non-mangrove waters; determine the content of heavy metals, especially $\mathrm{Pb}, \mathrm{Cu}, \mathrm{Cd}$, and $\mathrm{Hg}$ in green mussels cultivation.

\section{Materials and Methods}

The study used an experimental method adopted from Siregar (2013), by drawing a causal relationship from the type of material and the height of the green mussels collector from the bottom of the sea and the presence of mangroves with green mussels growth from aquaculture in Karangdempel coastal, Brebes Regency. Green mussels cultivation was done by floating box technique in coastal waters with a water depth of $125-150 \mathrm{~cm}$. Cultivation construction was designed with the type of mussels collector material made from coconut fiber, palm fiber, and nets sacks installed at the height of the collector's installation $20 \mathrm{~cm}, 30 \mathrm{~cm}$, and $40 \mathrm{~cm}$ from the mangrove and non-mangrove bottom.

The relationship of the growth of green mussels with the type and height of mussels collectors from the bottom of the waters and the presence of mangroves was analyzed by Analysis of Variance using SPSS software (Siregar, 2013).

\section{Results and Discussion}

The selection of research site was done under some criterias i.e. it should be protected from large waves assumed to be influenced by the flow of the Cisanggarung River, the base of mud-sandy waters, the depth of the waters $120-130 \mathrm{~cm}$, and the surrounding mangroves. The chosen location is the Karangdempel coastal area at the western end of Pasir Island, which is about 200 meters from Pasir Island to the south. Some of the Karangdempel beaches are overgrown with mangroves, alternating with mud-sandy beach land which is alluvial soil, like the coastal soil type of Brebes to Tegal (Wibowo et al., 2015). The land is relatively young but can support adequate water fertility for mangrove life. The waters with a lot of mangroves are ones of the habitats favored by $P$. viridis $L$. Green mussels are found mostly in bay waters, mangrove estuaries with sandy mud waters, in sites with adequate lighting and water movement and in sites in which salt levels are not too high (Sari and Harlyan, 2015).

There are two main types of mangrove vegetation found at Karangdempel coastal, namely Rhizophora sp. and Avicennia sp. with total species density, trees, saplings and seedlings each of 48 ind.ha-1, 26 ind.ha-1, 158 ind.ha-1, and 302 ind.ha-1. $^{-1}$. The closing of mangrove species is worth $7-20 \%$. Relatively large density values of species of seedlings and tillers and relatively small types of closure are indicated by the narrow shade of mangrove vegetation canopy because the mangrove vegetation is still dominated by sapling and seedling categories compared to the tree category as a result of the influence of mangrove reforestation in recent years. Domination of Rhizophora sp. is higher than Avicennia sp. because Rhizophora sp. is more easily seeded and planted during reforestation. Mangrove vegetation in Karangdempel coastal waters only has an ecological role with a low to moderate category which is shown by the range of important value index (IVI) which only ranges from 1 to 300 as stated by Bengen (2002). Mangrove vegetation in Karangdempel beach is categorised very rare and in a damaged condition indicated by the value of the Normalized Difference Vegetation Index (NDVI) of 0.096367 (Decree of the State Minister of Environment No.201 of 2004).

\section{Green mussels growth}

The cultivation of green mussels is indicated by the average mussels length, weight, and number of green mussels per collector mussels made from coir, palm fiber and nets sacks which are installed at a height of $20 \mathrm{~cm}, 30 \mathrm{~cm}$, and $40 \mathrm{~cm}$ from the bottom of the mangrove and non-mangrove waters. Green mussels growth at the end of the cultivation period (6 months maintenance period) is presented in Tables 1, 2 and 3.

The growth of green mussels with indicators of the shell length at the end of the maintenance period is influenced by the height of the mussels collector $(P=0.001)$ and the type of mussels collector material $(P=0.005)$ but not affected by the absence of mangrove $(P=0.227)$. The growth of the green mussels on the collectors which are hung at a height of $30 \mathrm{~cm}$ is very real and faster than the green mussels in the collector with a height of $20 \mathrm{~cm}$ and $40 \mathrm{~cm}$ from the bottom of the water. The growth of green mussels on nets collectors is significantly different and faster than those made from coir and palm fiber. The growth of green mussels in mangrove waters is not significantly different and relatively the same as those in waters with no mangroves.

The growth of green mussels with mussels weight indicators at the end of the maintenance period is influenced by the height of the mussel collector $(P=0.001)$ and the type of collector material $(P=0.024)$ but not affected by the absence of mangrove $(P=0.128)$. The weight of the green 
mussels on the collector which is hung at a height of $30 \mathrm{~cm}$ is significantly different and faster than the green mussels in the collector with a height of $20 \mathrm{~cm}$ and $40 \mathrm{~cm}$ from the bottom of the water. The weight of the $P$. viridis in the collector of mussels made of nets is significantly different and faster than those in the collector of coir and palm fiber. The weight of green mussels in mangrove waters is not significantly different from those in non-mangrove waters.

The number of green mussels per collector at the end of the culture period is influenced by the height of the mussels collector $(P=0.001)$ and the type of mussels collector material $(P=0.001)$ and the absence of mangrove plants (0.005). The number of green mussels per collector that is hung at a height of $30 \mathrm{~cm}$ is significantly different and more in number than the green mussels in the collector with a height of $20 \mathrm{~cm}$ and $40 \mathrm{~cm}$ from the bottom of the water. The amount of green mussels per collector made of nets is significantly different and more in number than that of green mussels in collectors made from coir and palm fiber. The amount of green mussels per collector in mangrove waters is significantly different and more abundant compared to those in non-mangrove waters.

\section{Water quality cultivation media}

Heavy metals contained in seawater and green mussels meat are still below the hazardous limits, except for copper $(\mathrm{Cu})$ content in green mussels meat which reaches 2,046-2,070 mg. kg-1 of meat, exceeding the permissible limit of $1.0 \mathrm{mg} . \mathrm{kg}^{-1}$ green mussels meat according to Indonesian National Standards (Government regulation number 82 of 2001, Decree of the Minister of Environment

Table 1. The average shell length $(\mathrm{cm} \pm \mathrm{SD})$ of green mussels (Perna viridis L.) at the end of the cultivation period

\begin{tabular}{|c|c|c|c|}
\hline \multirow{2}{*}{ Locations } & \multicolumn{3}{|c|}{ The height of the mussels collector from the bottom of the water } \\
\hline & $20 \mathrm{~cm}$ & $30 \mathrm{~cm}$ & $40 \mathrm{~cm}$ \\
\hline \multicolumn{4}{|l|}{ I. Non-mangrove } \\
\hline a. Coir collector & $7,10 \pm 0,0$ & $8,20 \pm 0,1$ & $8,00 \pm 0,0$ \\
\hline b. Fiber collector & $7,10 \pm 0,1$ & $8,20 \pm 0,1$ & $7,10 \pm 0,1$ \\
\hline c. Nets collector & $8,20 \pm 0,1$ & $9,50 \pm 0,1$ & $8,10 \pm 0,1$ \\
\hline \multicolumn{4}{|l|}{ II. Mangrove } \\
\hline a. Coir collector & $7,10 \pm 0,0$ & $8,10 \pm 0,0$ & $7,30 \pm 0,0$ \\
\hline b. Fiber collector & $8,20 \pm 0,0$ & $9,20 \pm 0,1$ & $8,10 \pm 0,1$ \\
\hline c. Nets collector & $8,20 \pm 0,1$ & $9,30 \pm 0,1$ & $8,20 \pm 0,1$ \\
\hline
\end{tabular}

Table 2. The average weight $(\mathrm{g} \pm \mathrm{SD}$ ) of green mussels (Perna viridis L.) at the end of the cultivation period

\begin{tabular}{lccc}
\hline \multirow{2}{*}{ Locations } & \multicolumn{2}{c}{ The height of the mussels collector from the bottom of the water } \\
\cline { 2 - 4 } & $20 \mathrm{~cm}$ & $30 \mathrm{~cm}$ & $40 \mathrm{~cm}$ \\
\hline I. Not mangrove & $10 \pm 1$ & $12 \pm 1$ & $10 \pm 1$ \\
a. Coir collector & $11 \pm 1$ & $12 \pm 1$ & $10 \pm 0$ \\
b. Fiber collector & $12 \pm 1$ & $13 \pm 0$ & $12 \pm 1$ \\
c. Nets collector & $11 \pm 1$ & $12 \pm 1$ & $12 \pm 1$ \\
\hline II. Mangrove & $11 \pm 1$ & $13 \pm 0$ & $11 \pm 1$ \\
a. Coir collector & $12 \pm 0$ & $13 \pm 0$ & $11 \pm 1$ \\
b. Fiber collector & & & \\
c. Nets collector & & & \\
\hline
\end{tabular}

Table 3. Total density of green mussels (Perna viridis L.) per collector at the end of the cultivation period

\begin{tabular}{lccc}
\hline \multicolumn{1}{c}{ Locations } & \multicolumn{2}{c}{ The height of the mussels collector from the bottom of the water } \\
\cline { 2 - 3 } & $20 \mathrm{~cm}$ & $30 \mathrm{~cm}$ & $40 \mathrm{~cm}$ \\
\hline I. Not mangrove & & $26 \pm 3,60$ & $24 \pm 3,00$ \\
a. Coir collector & $23 \pm 3,60$ & $26 \pm 2,65$ & $25 \pm 3,00$ \\
b. Fiber collector & $27 \pm 2,00$ & $30 \pm 1,73$ & $28 \pm 2,65$ \\
c. Nets collector & & & \\
II. Mangrove & $26 \pm 1,00$ & $28 \pm 2,65$ & $26 \pm 2,65$ \\
a. Coir collector & $28 \pm 1,00$ & $30 \pm 0,00$ & $25 \pm 2,00$ \\
b. Fiber collector & $28 \pm 1,73$ & $30 \pm 2,00$ & $29 \pm 1,00$ \\
c. Nets collector &
\end{tabular}


number 51 of 2004), but still below 20.0 mg.kg-1 as the maximum limit according to the provisions of the Decree of the Director General of Drug and Food Control, Ministry of Health Republic of Indonesia, number 03725/B/SK/1989. As for the sediments in the location of green mussels cultivation and in the Cisanggarung River basin, the $\mathrm{Pb}$ content is still within the safe limit. On the other hand, $\mathrm{Cd}, \mathrm{Cu}$, and $\mathrm{Hg}$ contained in the sediments in these three locations tend to be at the maximum permissible limit, even the $\mathrm{Cu}$ content in the Cisanggarung River channel reaches twice maximum allowable value.

The heavy metal content in green mussels meat, seawater, and sediment in the mangrove study sites with non-mangrove sites is not significantly different at the 95\% confidence level. This is indicated by the calculated $F$ value in the $t-$ test of 0.003 with a significance of 0.954 . Value $t$ (count) $=-0.028$ while from Table $t$ obtained value of $\mathrm{t}(\alpha / 2 ; \mathrm{df})=\mathrm{t}(0.025 ; 14)=2.14479$ so that obtained: -t table <t count <+t table $=-2,14479<-0,028<$ $+2,14479$, meaning there is no difference at $95 \%$ significance. This is possible because the condition of mangrove vegetation in Karangdempel beach is categorized as damaged with a range of important value index (IVI) 1-300 (Suyono et al., 2015) so that it only has a low to moderate ecological-economic role (Bengen, 2002). The relatively young age of mangrove vegetation resulting from reforestation has not been able to provide a significant positive impact on the coastal waters ecosystem including the heavy metal content. Good mangrove management will be able to increase coastal productivity including green mussels production (Fithor et al., 2018) (Table 4 and 5.).

\section{Conclusions}

The most effective collector mussels is made of nets sacks and was installed at a height of $30 \mathrm{~cm}$ from the bottom of the water. The number of mussels per collector in mangrove locations is higher compared to those in non-mangrove locations, while the growth (length and weight) of the mussels is relatively the same in both locations. In general, heavy metal content in seawater and in green mussels meat is still within the permissible limits, except for $\mathrm{Cu}$ content which exceeds the allowable limit according to Indonesian National Standards, but is it relatively safe according to the provisions of the Decree of the Director General of Drug Control and Food, Indonesian Ministry of Health, number: 03725/B/SK/1989. Pb content in sediments both in the location of green mussels cultivation and in the Cisanggarung River basin is still within safe limits. The content of $\mathrm{Cd}, \mathrm{Cu}$, and $\mathrm{Hg}$ in sediments tends to be high at the maximum permissible limit, even the $\mathrm{Cu}$ content in the Cisanggarung River reaches twice the maximum allowable value. The heavy metal content in the mangrove research sites with non-mangrove is relatively not significantly different as a result of the mangrove of reforestation which are still dominant seedlings and saplings so that the index of

Table 4. Results water quality measurement in the cultivation area

\begin{tabular}{|c|c|c|}
\hline No & Parameter & Value (Station: S $\left.06^{\circ} 47^{\prime \prime 39.9 " ' ~ E ~} 108^{\circ} 51^{\prime} 32.9^{\prime \prime}\right)$ \\
\hline 1 & Temperature & $33^{\circ} \mathrm{C}$ \\
\hline 2 & Air temperature & $34^{\circ} \mathrm{C}$ \\
\hline 3 & Depth & $125 \mathrm{~cm}$ \\
\hline 4 & Brightness & $30 \mathrm{~cm}$ \\
\hline 5 & Water $\mathrm{pH}$ & 7.4 \\
\hline 6 & Soil pH & 7,1 \\
\hline 7 & Salinity & $33 \% 0$ \\
\hline 8 & $\mathrm{O}_{2}$ & $8.68 \mathrm{ppm}$ \\
\hline 9 & Nitrous & $0.03 \mathrm{ppm}$ \\
\hline 10 & Nitrite & $0.001 \mathrm{ppm}$ \\
\hline 11 & Ammonia & $0.33 \mathrm{ppm}$ \\
\hline 12 & Phosphate & $0.002 \mathrm{ppm}$ \\
\hline 13 & Current speed & $0,1 \mathrm{~m} / \mathrm{sec}$ \\
\hline 14 & BOD & $5.30 \mathrm{ppm}$ \\
\hline 15 & Colors of water & Blue-green \\
\hline 16 & Plankton & $\begin{array}{c}\text { Synedra ulva, Sphatio sucatum, Ploesam triacatum, Rhopalodiaventricose, } \\
\text { Gramstopere serpentine, Pleurotaenium baculoides }\end{array}$ \\
\hline
\end{tabular}


Table 5. Results of Analysis of Heavy Metal Content of $\mathrm{Cu}, \mathrm{Cd}, \mathrm{Pb}$, and $\mathrm{Hg}$

1. Green mussels station 1

\begin{tabular}{|c|c|c|c|c|}
\hline & Unit & Test Result & Test Method & Locations \\
\hline Lead, $\mathrm{Pb}$ & mg.kg-1 & 0,470 & AAS & Not mangrove \\
\hline Cadmium, Cd & mg.kg-1 & $<0,010$ & AAS & Not mangrove \\
\hline Copper, $\mathrm{Cu}$ & mg.kg-1 & 2,070 & AAS & Not mangrove \\
\hline Mercury, Hg & mg.kg-1 & $<0,001$ & AAS & Not mangrove \\
\hline \multicolumn{5}{|c|}{ 2. Green mussels station 2} \\
\hline Parameters & Unit & Test Result & Test Method & Locations \\
\hline Lead, $\mathrm{Pb}$ & mg.kg-1 & 0,560 & AAS & Mangrove \\
\hline Cadmium, Cd & mg.kg-1 & $<0,010$ & AAS & Mangrove \\
\hline Copper, $\mathrm{Cu}$ & mg.kg-1 & 2,060 & AAS & Mangrove \\
\hline Mercury, $\mathrm{Hg}$ & mg.kg-1 & $<0,001$ & AAS & Mangrove \\
\hline \multicolumn{5}{|c|}{ 3. Seawater station 1} \\
\hline Parameters & Unit & Test Result & Test Method & Locations \\
\hline Lead, $\mathrm{Pb}$ & mg.t-1 & $<0,003$ & APHA & Not mangrove \\
\hline Cadmium, Cd & mg.t-1 & $<0,001$ & APHA & Not mangrove \\
\hline Copper, Cu & mg.t-1 & $<0,001$ & APHA & Not mangrove \\
\hline Mercury, $\mathrm{Hg}$ & mg.L-1 & $<0,001$ & APHA & Not mangrove \\
\hline \multicolumn{5}{|c|}{ 4. Seawater station 2} \\
\hline Parameters & Unit & Test result & Test Method & Locations \\
\hline Lead, $\mathrm{Pb}$ & mg.t-1 & $<0,003$ & APHA & Mangrove \\
\hline Cadmium, Cd & mg.L-1 & $<0,001$ & APHA & Mangrove \\
\hline Copper, Cu & mg.t-1 & $<0,001$ & APHA & Mangrove \\
\hline Mercury, Hg & mg.t-1 & $<0,001$ & APHA & Mangrove \\
\hline \multicolumn{5}{|c|}{ 5. Seawater of crossing of Cisanggarung River } \\
\hline Parameters & Unit & Test Result & Test Method & Locations \\
\hline Lead, $\mathrm{Pb}$ & mg.t-1 & $<0,003$ & APHA & Cisanggarung River \\
\hline Cadmium, Cd & mg.t-1 & $<0,001$ & APHA & Cisanggarung River \\
\hline Copper, $\mathrm{Cu}$ & mg.t-1 & $<0,001$ & APHA & Cisanggarung River \\
\hline Mercury, $\mathrm{Hg}$ & mg.L-1 & $<0,001$ & APHA & Cisanggarung River \\
\hline \multicolumn{5}{|c|}{ 6. Sea bed sediment station 1} \\
\hline Parameters & Unit & Test Result & Test Method & Locations \\
\hline Lead, $\mathrm{Pb}$ & mg.kg-1 & 25,820 & $\begin{array}{l}\text { The US.EPA SW 846/3050 } \\
\text { B-1996 SM 3111B-2012 }\end{array}$ & Not mangrove \\
\hline Cadmium, Cd & mg.kg-1 & 1,683 & $\begin{array}{l}\text { The US.EPA SW 846/3050 } \\
\text { B-1996 SM 3111B-2012 }\end{array}$ & Not mangrove \\
\hline Copper, Cu & mg.kg-1 & 24,430 & $\begin{array}{l}\text { The US.EPA SW 846/3050 } \\
\text { B-1996 SM 3111B-2012 }\end{array}$ & Not mangrove \\
\hline Mercury, Hg & mg.kg-1 & 0,146 & $\begin{array}{l}\text { The US.EPA SW 846/3050 } \\
\text { B-1996 SM 3111B-2012 }\end{array}$ & Not mangrove \\
\hline \multicolumn{5}{|c|}{ 7. Seabed sediment station 2} \\
\hline Parameters & Unit & Test Result & Test Method & Locations \\
\hline Lead, $\mathrm{Pb}$ & mg.kg-1 & 33,250 & $\begin{array}{l}\text { The US.EPA SW846/3050 B- } \\
1996 \text { SM 3111B-2012 }\end{array}$ & Mangrove \\
\hline Cadmium, Cd & mg.kg-1 & 2,089 & $\begin{array}{l}\text { The US.EPA SW846/3050 } \\
\text { B-1996 SM 3111B-2012 }\end{array}$ & Mangrove \\
\hline Copper, Cu & mg.kg-1 & 29,700 & $\begin{array}{l}\text { The US.EPA SW 846/3050 B- } \\
1996 \text { SM 3111B-2012 }\end{array}$ & Mangrove \\
\hline Mercury, $\mathrm{Hg}$ & mg.kg-1 & 0,182 & $\begin{array}{l}\text { The US.EPA SW 846/3050 } \\
\text { B-1996 SM 3111B-2012 }\end{array}$ & Mangrove \\
\hline \multicolumn{5}{|c|}{ 8. Basic sediments of the crossing of Cisanggarung River } \\
\hline Parameters & Unit & Test Result & Test Method & Locations \\
\hline Lead, $\mathrm{Pb}$ & mg.kg-1 & 31,600 & $\begin{array}{c}\text { The US.EPA SW 846/3050 } \\
\text { B-1996 SM 3111B-2012 }\end{array}$ & Cisanggarung River \\
\hline Cadmium, Cd & mg.kg-1 & 2,084 & $\begin{array}{c}\text { The US.EPA SW 846/3050 } \\
\text { B-1996 SM 3111B-2012 }\end{array}$ & Cisanggarung River \\
\hline Copper, Cu & mg.kg-1 & 70,850 & $\begin{array}{l}\text { The US.EPA SW 846/3050 } \\
\text { B-1996 SM 3111B-2012 }\end{array}$ & Cisanggarung River \\
\hline Mercury, Hg & mg.kg-1 & 0,174 & $\begin{array}{l}\text { The US.EPA SW 846/3050 } \\
\text { B-1996 SM 3111B-2012 }\end{array}$ & Cisanggarung River \\
\hline
\end{tabular}


importance/role has not yet affected the ecologicaleconomic quality of the waters.

\section{Acknowledgment}

Thank you to the Directorate of Research and Community Service, the Ministry of Research and Technology and the Regional Development Planning, Research, and Development Agency of Brebes Regency that has funded this research as a material for writing this journal article.

\section{References}

Brebes Regency Indonesian Fishermen Association. 2017. Brebes Regency in 2017 Figures.

Cirebon Regency Statistics Agency. 2017. Cirebon Regency in 2017 Figures.

Cirebon City Central Bureau of Statistics. 2017. The City of Cirebon in 2017 Figures.

Kuningan Regency Central Bureau of Statistics. 2017. Kuningan Regency in 2017 Figures

Bengen. D.G. 2002. Introduction to Technical Guidelines and Management of Mangrove Forests. IPB. Bogor. 87 p.

Fisheries and Marine Services of Brebes Regency. 2008. Preparation of the Coastal Spatial Plan for Brebes Regency. 56 p.

Fithor, A., Sutrisno, J. \& Indarjo, A. 2018. Mangrove Ecosystem Management Strategy in Maron Beach Semarang. IImu Kelautan 23(4): 156162. doi: 10.14710/ik.ijms.23.4.156-162

Heriyanto, N.M. 2011. Heavy Metal Content in Plants, Soil, Water, Fish and Shrimp in Mangrove Forests. Plantation Res. J. 8 (4):197205.

The Indonesian Fishermen's Association of Brebes Regency. 2017. Community Participation in
Fish Resource Management to be Sustainable and Sustainable.

Government Regulation. 2001. No. 82 concerning Water Quality Regulations and Water Pollution Control.

Kusumastuti, W., Hendrarto, B. \& Sutrisnanto, D. 2011. Evaluation of Wetland Artificial Mangrove Vegetation in Reducing Environmental Pollution, Case Study in Kepetingan Village, Sidoarjo Regency. J. Environ. Sci., 9(2): 69 - 74.

Sari, S.H.J. \& Harlyan, L.I. 2015. Feasibility of Aquatic Quality Around Tuban Center Mangroves for Application of Green Mussels Collecting Equipment (Perna viridis L.). Res. J. Life Sci. 2(1): 60-68.

Siregar, S. 2013. Parametric Statistics for Quantitative Research. PT Bumi Aksara. Jakarta. 538 p.

Decree of the Director General of Drug and Food Control. 1989. Ministry of Health of the Republic of Indonesia, No. 03725/B/SK/1989.

Supriyantini, E. \& Soenardjo, N. 2015. Heavy Metal Content of Lead $(\mathrm{Pb})$ and Copper $(\mathrm{Cu})$ at the Roots and Fruit of Mangrove Avicennia marina in Tanjung Emas Waters Semarang. Trop. Mar. J. 18(2): 98-106.

Suyono, Supriharyono, Hendarto, B. \& Radjasa, O.K. 2015. Management Strategies of Mangrove Degradation in Coastal Areas of Brebes Regency, Central Java, Indonesia. Int. J. Coast. Zone Manag. 18(2): 1-12. doi: 10.4172/ 24733350.1000401

Wibowo, P.L.A., Hartoko, A., \& Ambariyanto. 2015. Land Subsidence Affects Coastal Zone Vulnerability. IImu Kelautan. 20(3): 27-134. doi: 10.14710/ik.ijms.20.3.127-134. 